\title{
UPAYA MENCIPTAKAN LINGKUNGAN TEMPAT KERJA SEHAT DAN BERSIH SELAMA MASA PANDEMI
}

\author{
Susy Olivia Lontoh ${ }^{1}$, Yemima Graciela ${ }^{2}$ \\ ${ }^{1}$ Bagian Ilmu Fisiologi Fakultas Kedokteran Universitas Tarumanagara, Jakarta \\ Email: susyo@fk.untar.ac.id \\ ${ }^{2}$ Mahasiswa Fakultas Kedokteran Universitas Tarumanagara, Jakarta \\ Email: yemimagraciella@gmail.com
}

\begin{abstract}
Pharmacies and health professionals, including Pharmacists, assistant Pharmacists, and the cashier is one of the groups most at risk of contracting the virus Covid-19 during the pandemic Covid 19 dispensaries a place that is often accessible to the public because it provides services to the needs of the patient medications. Based on these problems, then do the activities to protect the workplace to reduce the risk of transmission in the workplace and pharmacies keep doing every drug but not be the area of transmission of the virus Covid-19. The purpose of community service is to improve the awareness, knowledge, attitudes, and behavior through training and education protocol-related health in the workplace the right so that can create a healthy work environment. Activities conducted June 17, 18,24 and 25 September 2021 environment dispensary in West Jakarta. The activities of 17-18 September 2021 conduct a preliminary survey to fill out the questionnaire with the google form linked the use of masks in the workplace, the habit of washing hands and clean the work place. The results of the questionnaire of 26 respondents was $15.4 \%$ of the respondents do not use the mask for work, the $23.1 \%$ of the respondents rarely use mask properly, a $34.6 \%$ rarely wash hands before work, $23,1 \%$ not important to wash hands before and after work and $23.1 \%$ not important clean work environment with a disinfectant and clean the work place before and after work. PKM September 24, 2021 is the practice of how to wash hands in accordance with the recommendation of the Ministry of health, using the appropriate mask and face shield in the workplace. PKM activity carried out from September 25, 2021 manufacture means the place of hand washing common, put up a plastic barrier and spraying disinfectant in the area pharmacies. The activities of a community service program implemented well, after the implementation of community service activities is then the habit of washing hands before and after work, consumers wash their hands with water in place of washing hands before going into the area of the dispensary, the mask is worn according to the rules can continue to be done so that there is increased awareness of the workers and consumers in the workplace to create a healthy working environment during the pandemic.
\end{abstract}

Keywords: workplace, education protocol health, personal hygiene, and work environment

\section{ABSTRAK}

Apotik dan tenaga kesehatan termasuk Apoteker, asisten Apoteker serta kasir merupakan salah satu kelompok yang paling berisiko tertular virus Covid-19 karena selama pandemi Covid 19 apotik tempat yang sering diakses masyarakat karena memberikan pelayanan untuk kebutuhan obat pasien. Berdasarkan permasalahan tersebut maka dilakukan kegiatan untuk melindungi tempat kerja untuk menurunkan risiko penularan di tempat kerja dan apotik tetap melakukan pelayanan obat tetapi tidak menjadi area penularan virus Covid-19. Tujuan kegiatan pengabdian adalah meningkatkan kesadaran, pengetahuan, sikap dan perilaku melalui pelatihan serta edukasi terkait protokol kesehatan ditempat kerja yang tepat sehingga dapat menciptakan lingkungan kerja yang sehat. Kegiatan dilakukan tanggal 17, 18,24 dan 25 September 2021 dilingkungan apotik di Jakarta Barat. Kegiatan tanggal 17-18 September 2021 melakukan survei awal mengisi kuisioner dengan google form terkait penggunaan masker ditempat kerja, kebiasaan mencuci tangan serta membersihkan tempat kerja. Hasil kuisioner dari 26 responden adalah 15,4\% responden tidak penting menggunakan masker selama bekerja, 23,1\% responden jarang menggunakan masker dengan tepat, $34,6 \%$ jarang mencuci tangan sebelum bekerja $, 23,1 \%$ tidak penting mencuci tangan sebelum dan sesudah bekerja dan 23,1\% tidak penting membersihkan lingkungan kerja dengan desinfektan serta membersihkan tempat kerja sebelum dan sesudah bekerja. Kegiatan PKM tanggal 24 September 2021 adalah praktik cara mencuci tangan sesuai anjuran Kemenkes, menggunakan masker yang tepat serta face shield ditempat kerja. Kegiatan PKM yang dilakukan tanggal 25 September 2021 pembuatan sarana tempat cuci tangan umum, memasang plastik pembatas dan penyemprotan desinfektan di area apotik. Kegiatan program pengabdian masyarakat terlaksana dengan baik, setelah terlaksananya kegiatan pengabdian masyarakat ini maka kebiasaan mencuci tangan sebelum dan setelah bekerja, konsumen mencuci tangan dengan air di tempat cuci tangan sebelum masuk ke area apotik, masker dipakai sesuai aturan dapat terus terlaksana sehingga terjadi peningkatan kesadaran pekerja serta konsumen ditempat kerja untuk menciptakan lingkungan kerja yang sehat selama pandemi. 
Kata kunci: Tempat kerja, edukasi protokol kesehatan, kebersihan diri dan lingkungan kerja

\section{PENDAHULUAN}

Merespons pandemi COVID-19 yang sedang berlangsung, negara di seluruh dunia telah melakukan sejumlah langkah untuk mencegah penyebaran virus Covid-19 melalui masyarakat, seperti larangan bepergian ke luar negeri dan interaksi sosial yang dibatasi ruang geraknya. Kondisi perkembangan epidemiologis penyakit saat ini berubah dari waktu ke waktu, beberapa negara, termasuk Indonesia, perlahan mulai membuka kembali pekerjaan mereka untuk mempertahankan aktivitas dan berbagai upaya terus dilakukan agar perekonomian tetap berjalan, namun diperlukan langkah preventif di area kerja (WHO,2020). Tempat kerja dapat memberikan kontribusi yang signifikan terhadap penularan penyakit menular melalui interaksi dan pertemuan dengan pekerja karena penyebaran virus Covid 19 melalui percikan udara, kontak langsung dengan permukaan alat kerja yang sudah terpapar virus Covid 19 (Su et al. 2019).

Paparan virus Covid-19 di tempat kerja dapat terjadi kapan saja, dimana saja seperti di jalan saat berangkat dan pulang kerja atau berinteraksi dengan pekerja atau pelanggan (Michael B, 2020). Penyebaran COVID-19 dapat melalui percikan udara dan menyentuh benda atau peralatan kerja yang terpapar droplet virus Covid19 (Koh, 2020). Risiko pajanan COVID-19 di tempat kerja sangat bergantung pada kemungkinan kontak dekat atau terpapar dengan orang yang mungkin terinfeksi COVID-19, oleh karena itu perlu dilakukan tindakan pencegahan di tempat kerja, seperti penerapan aturan penggunaan masker yang benar serta menyediakan fasilitas Kesehatan untuk mengurangi risiko terpapar COVID19 di tempat kerja. Penelitian yang ada belum secara meyakinkan menghubungkan penularan virus COVID-19 ke permukaan perabotan di lingkungan kerja seperti gagang pintu, sakelar lampu, meja, tembok, namun, perlu diperhatikan kontaminasi di tempat kerja kesehatan seperti Apotik (WHO, 2020; IRF,2020)

\section{Permasalahan Mitra}

Apotik dan tenaga kesehatan termasuk Apoteker, asisten Apoteker, staf farmasi dibagian depan serta kasir merupakan salah satu kelompok yang paling berisiko tertular virus Covid-19 karena selama pandemi Covid 19 apotik tempat yang sering diakses masyarakat karena memberikan pelayanan tatap muka untuk kebutuhan obat pasien. Berdasarkan permasalahan resiko penularan Covid-19 sangat tinggi di tempat kerja dan kurang kesadaran dalam penerapan standar protokol kesehatan yang baik serta fasilitas penunjang dalam pencegahan Covid-19 yang masih terbatas. Berdasarkan permasalahan tersebut maka dilakukan kegiatan untuk melindungi tempat kerja untuk menurunkan risiko penularan di tempat kerja dan apotik tetap melakukan pelayanan obat tetapi tidak menjadi area penularan virus Covid-19. Tujuan kegiatan pengabdian adalah meningkatkan kesadaran, pengetahuan serta perilaku melalui pelatihan serta edukasi terkait protokol kesehatan ditempat kerja yang tepat sehingga dapat menciptakan lingkungan kerja yang sehat.

\section{METODE PELAKSANAAN PKM}

Solusi dalam kegiatan pengabdian ini adalah melakukan survei awal berupa kuisioner, pelatihan edukasi terkait protokol kesehatan ditempat kerja yang tepat dan menyediakan fasilitas cuci tangan umum. Manfaat dari kegiatan PKM adalah meningkatnya kesadaran, pengetahuan terkait protokol kesehatan dilingkungan kerja sebagai upaya menjaga, memelihara dan meningkatkan kesehatan. Target jangka pendek adalah tempat kerja Apotik dan para pekerja dapat menerapakan prosedur kesehatan dengan tepat dan target jangka panjangnya adalah meningkatkan derajat kesehatan serta produktivitas para pekerja. 
Tim pengabdian bekerja sama dengan pekerja dan beberapa konsumen melakukan survei awal berupa kuisioner terkait lingkungan kerja dan kesadaran penggunaan masker, mencuci tangan sebelum dan sesudah aktivitas, pentingnya membersihkan area kerja sebelum dan sesudah kegiatan pekerjaan dilakukan. Bekerja sama dengan pekerja dalam penyiapan tempat mencuci tangan, memberikan edukasi tentang protokol kesehatan di tempat kerja terkait cara mencuci tangan yang tepat sesuai anjuran WHO, penggunaan masker, face shield, sarung tangan dengan tepat, menyiapkan handsanitizer dan penyemprotan desinfektan pada tembok, meja, kursi, dan berbagai permukaan di lingkungan kerja. Metode kegiatan PKM yang dilakukan adalah pelatihan disertai praktik tentang mencuci tangan dengan benar sesuai aturan WHO, pemakaian masker sesuai dengan standar yang tepat, melakukan pembersihan di area kerja terutama tembok, permukaan meja, lantai, membiasakan menggunakan sarung tangan saat pelayanan obat, memasang plastik pemisah di area kasir untuk memberi jarak dalam pelayanan tatap muka serta membuat tempat cuci tangan sederhana yang dipasang di depan area apotik serta menyediakan handsanitizer di depan pintu masuk dan ruang pembuatan obat.

\section{HASIL DAN PEMBAHASAN}

Program Pengabdian Masyarakat dalam upaya menciptakan lingkungan kerja yang sehat dan bersih selama masa pandemi Covid-19 pada kelompok pekerja di Apotik Jakarta Barat dapat terlaksana dan direalisasikan dengan baik. Pekerja dilingkungan apotik berpartisipasi langsung dan antusias mengikuti survei awal, pelatihan disertai praktik tentang mencuci tangan dengan benar sesuai aturan WHO, pemakaian masker sesuai dengan standar yang tepat, melakukan pembersihan di area kerja terutama tembok, permukaan meja, lantai, membiasakan menggunakan sarung tangan saat pelayanan obat. Tanggal 17-18 September 2021 melakukan survei awal berupa kuisioner (google form) yang disebarkan secara daring yang berisi pertanyaan terkait penggunaan masker ditempat kerja, kebiasaan mencuci tangan serta membersihkan tempat kerja.

Hasil kuisioner dari 26 responden didapatkan 15,4\% responden menyatakan tidak penting menggunakan masker selama bekerja, 23,1\% responden jarang menggunakan masker dengan tepat, 34,6\% jarang mencuci tangan sebelum bekerja , 23,1\% responden memilih tidak penting mencuci tangan sebelum dan sesudah bekerja dan 23,1\% memilih tidak penting membersihkan lingkungan kerja dengan desinfektan serta membersihkan tempat kerja sebelum dan sesudah bekerja.

Menggunakan masker selama bekerja 26 jawaban

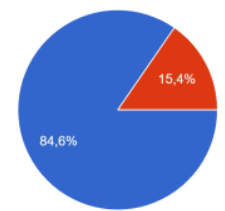

Mencuci

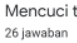

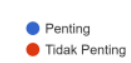

Mengguna
26 jawaban

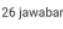

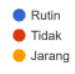

Mencuci tangan sebelum dan sesudah bekerja
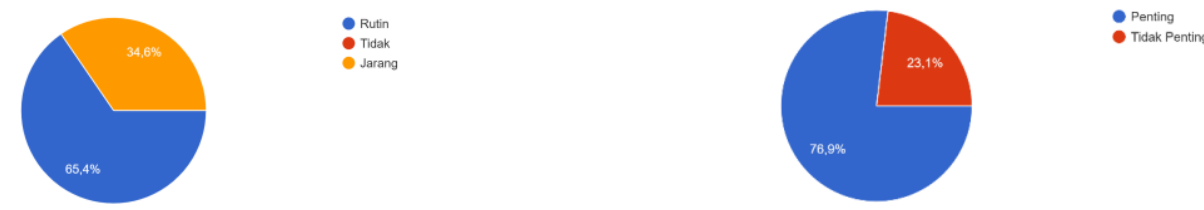

Menggunakan desinfektan di tempat kerja
26 jawaban

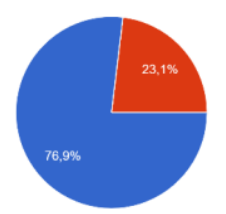

Me ? 26 jawabar

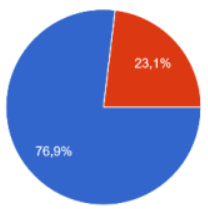

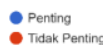

Gambar 1. Diagram Hasil Kuisioner

Kegiatan PKM tanggal 24 September 2021 adalah praktik mencuci tangan sesuai anjuran Kemenkes. Mencuci tangan menggunakan sabun cuci tangan serta air mengalir dan dilakukan selama 60 detik diterapkan saat sebelum melakukan aktivitas, saat sampai di tempat kerja, setelah menerima uang, sebelum dan sesudah makan atau setelah dari kamar kecil. Kegiatan ini juga dilakukan edukasi cara menggunakan masker dengan tepat sesuai anjuran Kemenkes serta menggunakan face shield ditempat kerja. Masker yang dianjurkan adalah masker 2 lapis yaitu masker bedah dan masker kain. Masker digunakan menutup mulut, hidung dan dagu serta tidak dilepaskan selama bekerja. Tim juga membagikan flyer terkait cuci tangan serta cara memakai masker.

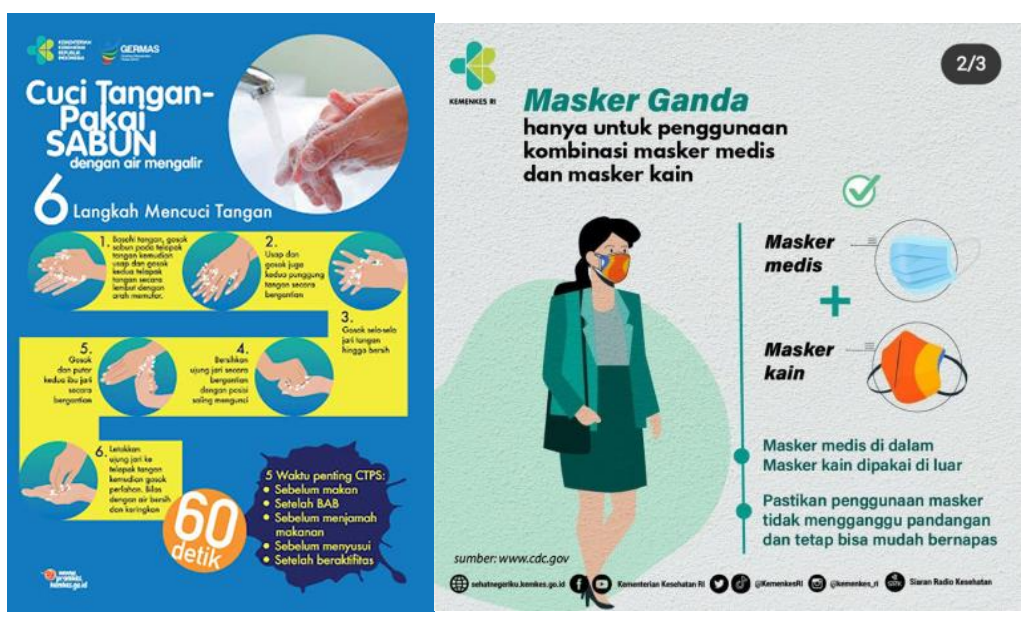



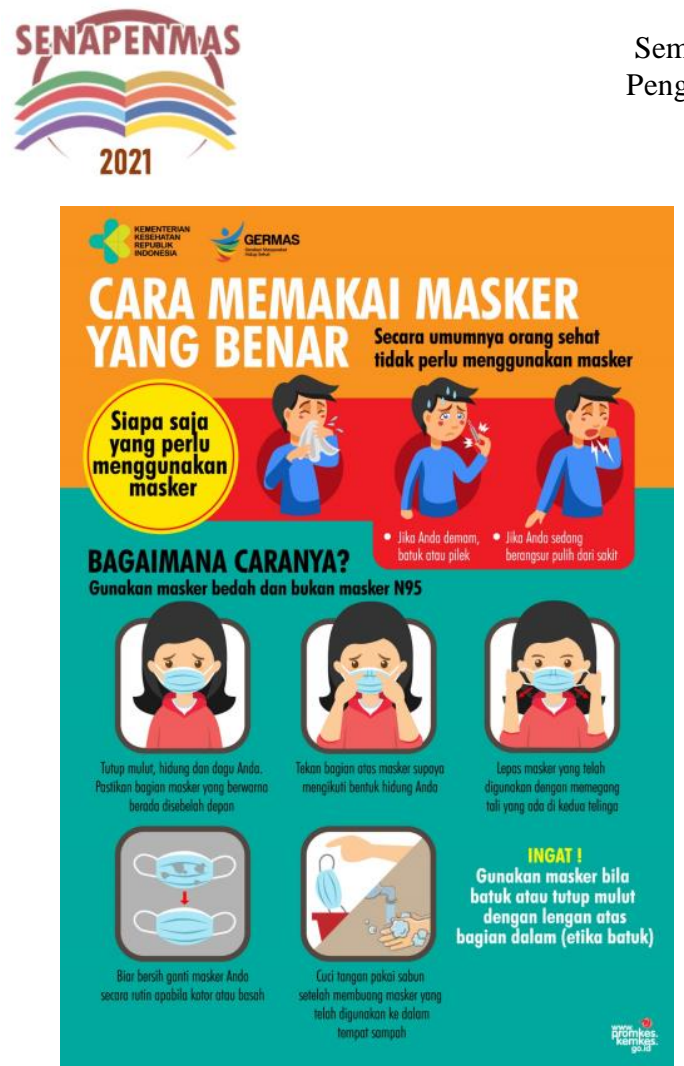

Seminar Nasional Hasil Penelitian dan Pengabdian Kepada Masyarakat 2021

Pengembangan Ekonomi Bangsa Melalui Inovasi Digital Hasil Penelitian dan Pengabdian Kepada Masyarakat Jakarta, 21 Oktober 2021

\section{Gambar 2. Flyer Cuci Tangan, Penggunaan Masker yang disampaikan oleh TIM PKM}

(Kemenkes, 2020)

Kegiatan PKM yang dilakukan tanggal 25 September 2021 adalah penyemprotan desinfektan di lingkungan Apotik, pembersihan di area kerja terutama tembok, permukaan meja, lantai, membiasakan menggunakan sarung tangan saat pelayanan obat, memasang plastik pemisah di area kasir untuk memberi jarak dalam pelayanan tatap muka serta membuat tempat cuci tangan sederhana yang dipasang di depan area apotik serta menyediakan handsanitizer di depan pintu masuk dan ruang pembuatan obat.

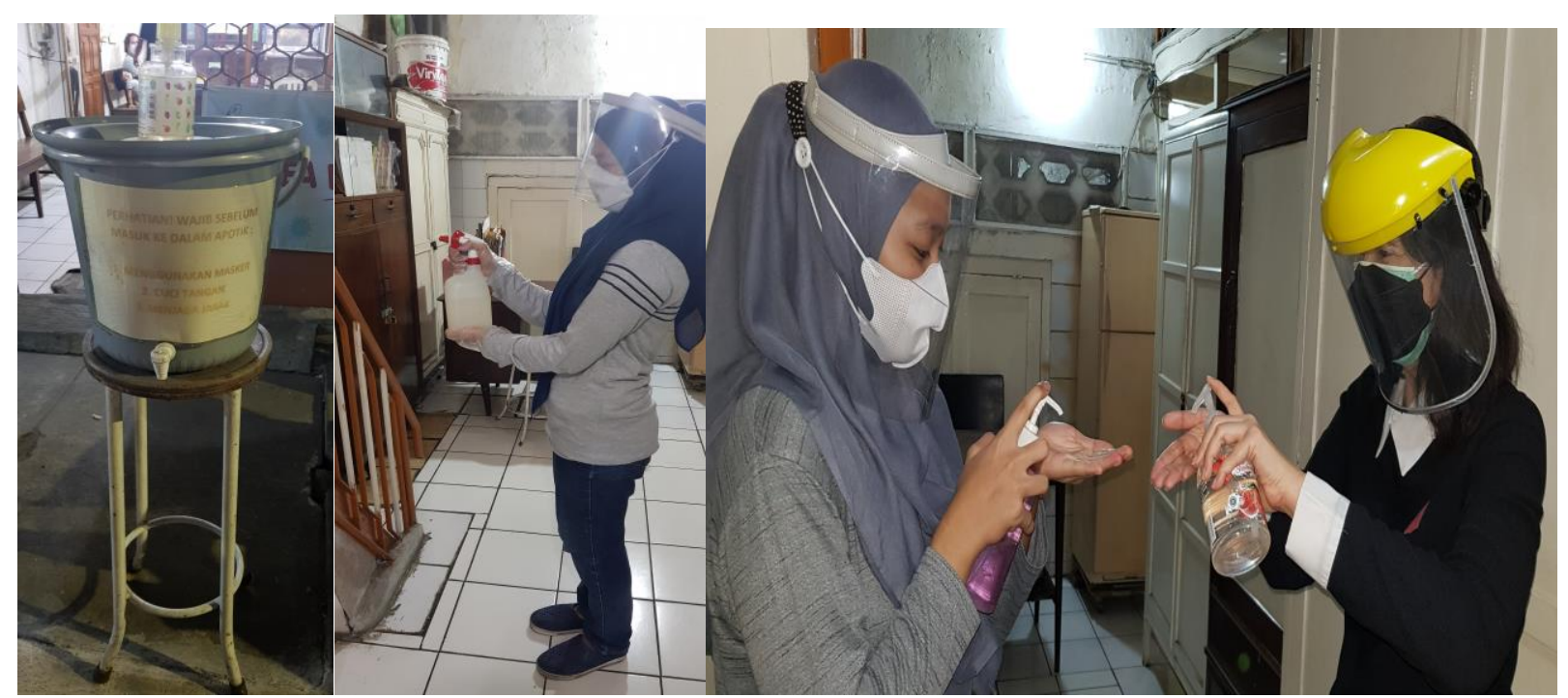




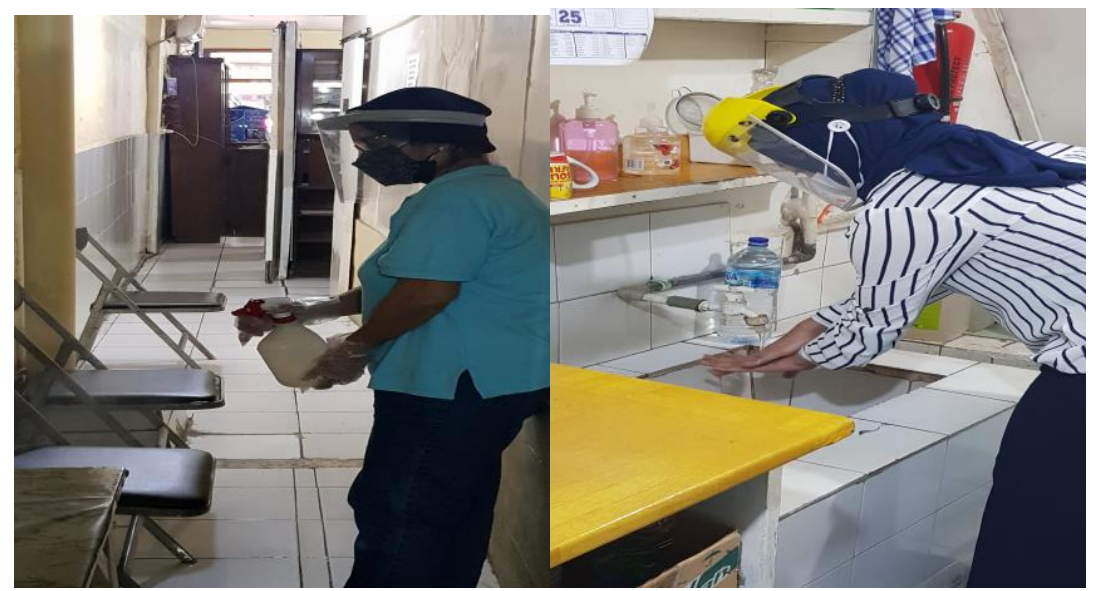

Gambar 3. Kegiatan PKM berupa Cuci Tangan, Desinfektan, tempat cuci tangan dan handsanitizer

\section{KESIMPULAN}

Kegiatan pengabdian masyarakat di lingkungan apotik yang dilakukan dari tanggal 17, 18, 24 dan 25 September terlaksana dengan baik. Hasil dari kuisioner didapatkan rendahnya kesadaran mencuci tangan sesuai anjuran Kemenkes, memakai masker denagn tepat selama bekerja serta tidak penting membersihkan lingkungan kerja maka dilakukan praktik serta edukasi langsung terkait mencuci tangan sebelum dan setelah bekerja, konsumen mencuci tangan dengan air di tempat cuci tangan sebelum masuk ke area apotik, menggunakan masker dengan tepat sesuai anjuran, menyiapkan handsanitizer dan rutin melakukan penyemprotan desinfektan di lingkungan kerja, juga dilakukan pembuatan tempat cuci tangan sederhana yang dipasang di depan area apotik, menyediakan handsanitizer di depan pintu masuk dan ruang pembuatan obat dan memasang plastik pemisah di area kasir untuk memberi jarak dalam pelayanan tatap muka Pemasangan flyer edukasi tentang menerapkan pemakaian masker dengan tepat, menggunakan face shield serta sarung tangan sebagai bagian pelindung diri serta menyiapkan handsanitizer, membiasakan menggunakan sarung tangan saat pelayanan di apotik. Perubahan yang didapat setelah terlaksananya program pengabdian masyarakat adalah menerapkan kebiasaan mencuci tangan sebelum dan setelah bekerja, konsumen mencuci tangan dengan air di tempat cuci tangan sebelum masuk ke area apotik, masker dipakai sesuai aturan sehingga terjadi peningkatan kesadaran pekerja serta konsumen ditempat kerja untuk menciptakan lingkungan kerja yang sehat selama pandemi. Kegiatan ini dapat berkelanjutan dengan melakukan evaluasi atas kegiatan pengabdian yang telah dilakukan serta melakukan kuisioner umpan balik terkait kegiatan pengabdian yang berhubungan lingkungan kerja.

\section{Ucapan Terima Kasih}

Terima kasih kami haturkan kepada Lembaga Penelitian dan Pengabdian kepada Masyarakat Universitas Tarumanagara atas pendanaan dalam kegiatan ini. Terima kasih kepada seluruh peserta yang berpartisipasi dalam kegiatan bakti kesehatan, sehingga kegiatan dapat dilakukan sesuai rencana. Terima kasih juga disampaikan kepada Tim PKM atas kesempatan dan dukungannya dalam pelaksanaan kegiatan bakti kesehatan ini. Tim Senapenmas 2021 atas kesempatan mengikuti kegiatan Senapenmas 2021. 


\section{REFERENSI}

Covid19. (2020). Cuci Tangan Pakai Sabun. https://covid19.go.id/edukasi/masyarakatumum/cuci-tangan-pakai-sabun

IFRC, IOM, UNHCR and WHO (2020). Interim Guidance on Scaling-up COVID-19 Outbreak in Readiness and Response Operations in Camps and Camp-like Settings https://interagencystandingcommittee.org/other/interim-guidance-scaling-covid-19outbreak-readiness-and-response-operations-camps-and-camp

Kemenkes.Beginilah Cara Memakai dan Melepaskan Masker yang Benar. (2020). https://infeksiemerging.kemkes.go.id/warta-infem/beginilah-cara-memakai-danmelepaskan-masker-yang-benar-140

Koh D. (2020) Occupational risks for COVID-19 infection, Occupational Medicine 2020;70:82-83 https://www.ncbi.nlm.nih.gov/pmc/articles/PMC7107962/

Michael B, Maria E. P, Michele A. R.(2020). COVID-19: Health prevention and control in nonhealthcare settings, Occupational Medicine 2020;70:82-83 https://www.ncbi.nlm.nih.gov/pmc/articles/PMC7188129/

WHO.(2020) . Occupational safety and health in public health emergencies: a manual for protecting health workers and responders, WHO and ILO, https://www.who.int/publications-detail/occupational-safety-and-health-in-public-healthemergencies-a- manual-for-protecting-health-workers-and-responders

Su. C.P,Perio, M,Cummings, K , McCague, A.B, Luckhaupt, S, Sweeney, M. (2019). "Investigasi Kasus Penyakit Menular yang Terjadi di Tempat Kerja, Amerika Serikat, 2006-2015". Penyakit menular yang muncul. 25. 397-405. https://studylibid.com/doc/4326180/ilo-pandemi-corona

WHO (2020), Operational considerations for COVID-19 management in the accommodation sector https://apps.who.int/iris/bitstream/handle/10665/331937/WHO-2019-nCoV-Hotels2020.2-eng.pdf

WHO dan FAO (2020), COVID-19 and food safety: guidance for food businesses, https://apps.who.int/iris/bitstream/handle/10665/331705/WHO-2019-nCoV-Food_Safety2020.1-eng.pdf

WHO (2020) Operational considerations for managing COVID-19 cases or outbreak in aviation: interim guidance, https://apps.who.int/iris/rest/bitstreams/1272369/retrieve

WHO (2020) Water, sanitation, hygiene, and waste management for the COVID-19 virus: interim guidance, 23 April 2020, https://apps.who.int/iris/rest/bitstreams/1275547/retrieve

WHO (2020) Considerations in adjusting public health and social measures in the context of COVID-19 (Interim Guidance,16 April 2020) (WHO 2020). https://www.who.int/publications-detail/considerations-in-adjusting-public-health-andsocial-measures-in-the-context-of-covid-19-interim-guidance 
Seminar Nasional Hasil Penelitian dan Pengabdian Kepada Masyarakat 2021

Pengembangan Ekonomi Bangsa Melalui Inovasi Digital Hasil Penelitian dan

Pengabdian Kepada Masyarakat

Jakarta, 21 Oktober 2021

(halaman kosong) 